\title{
A 250-year drought catalogue for the island of Ireland (1765-2015)
}

\author{
S. Noone, ${ }^{\mathrm{a}}$ C. Broderick, ${ }^{\mathrm{a}}$ C. Duffy, ${ }^{\mathrm{a}}$ T. Matthews, ${ }^{\mathrm{b}}$ R.L. Wilby ${ }^{\mathrm{c}}$ and C. Murphy ${ }^{\mathrm{a} *}$ \\ ${ }^{a}$ Irish Climate Analysis and Research UnitS (ICARUS), Department of Geography, Maynooth University, Kildare, Ireland \\ ${ }^{\mathrm{b}}$ School of Natural Sciences and Psychology, Liverpool John Moores University, Liverpool, England, UK \\ ${ }^{\mathrm{c}}$ Department of Geography, Loughborough University, Loughborough, England, UK
}

\begin{abstract}
This work created a 250-year historic drought catalogue by applying the Standardized Precipitation Index (SPI) to the Island of Ireland precipitation network (1850-2015) and a reconstructed precipitation series from 1765. Documentary sources from newspaper archives spanning the last 250 years, together with other historical sources are used to (1) add confidence to the quantitative detection of drought episodes and (2) gain insight to the socio-economic impacts of historic droughts. The results show that Ireland is drought prone but recent decades are unrepresentative of the longer-term drought climatology. A large decline in 30-year accumulated SPI-12 values is evident from around the 1990s onwards. During the years 1850-2015 seven major drought rich periods were identified with an island-wide fingerprint in 1854-1860, 1884-1896, 1904-1912, 1921-1923, 1932-1935, 1952-1954 and 1969-1977. These events exhibit substantial diversity in terms of drought development, severity and spatial occurrence. Two exceptionally long events are found in the record: the continuous drought of 1854-1860 and the drought of 1800-1809 (in fact a series of three droughts with brief interludes). Over the last 250 years, droughts have resulted in agricultural hardship, water resource crises and failures and preceded some of the major famines of the eighteenth and nineteenth centuries. This work shows that newspaper archives can be used to trace the progression of drought events and impacts and we thus advocate their wider use in corroborating quantitative assessments. The resulting catalogue challenges prevailing perceptions about drought in Ireland while strengthening the evidence base for future drought and water resource planning across the island.
\end{abstract}

KEY WORDS drought; Standardized Precipitation Index; documentary sources; newspaper archives; climate reconstructions; Ireland

Received 14 June 2016; Revised 11 November 2016; Accepted 19 December 2016

\section{Introduction}

Recent decades have witnessed severe drought events across Europe (Fink et al., 2004; Marsh, 2004; Todd et al. 2013; Lennard et al., 2014; Spinoni et al., 2015) with serious impacts including reductions or loss of water supply, decreased agricultural production and power generation, environmental degradation and even loss of life (Cole and Marsh, 2006; Briffa et al., 2009; Hannaford et al., 2011; Lennard et al., 2014). Appropriate drought planning, particularly in the context of future climate change begins with understanding the magnitude and socio-economic impacts of past events. To this end, a growing number of studies are using long-term observations alongside documentary evidence to identify and assess historical droughts (Mishra and Singh, 2010; Gosling et al., 2012; Watts et al., 2012; Lennard et al., 2014, 2015; Kingston et al., 2015).

For example, Marsh et al. (2007) and Cole and Marsh (2006) identify periods of prolonged drought in the UK during 1854-1860 and 1890-1910 -which were

* Correspondence to: C. Murphy, Irish Climate Analysis and Research UnitS (ICARUS), Department of Geography, Maynooth University, Kildare, Ireland. E-mail: conor.murphy@nuim.ie attributed to sequences of dry winter and summer seasons. Using long-term observations (1697-2011) Todd et al. (2013) reconstructed droughts across the southeast UK, identifying several drought rich periods including 1943-1950 and 1970-1978. Spraggs et al. (2015) identified long-drought periods in the nineteenth century, with the most notable being 1854-1860 for the Anglian region (UK). Barker et al. (2004) reconstructed a 200-year precipitation series for the Central Lake District (northwest England), noting prolonged dry spells in the 1850s, 1880s, 1930s and 1970s.

Going back further in time, Brázdil et al. (2013) used documentary, proxy and instrumental sources to reconstruct droughts for the Czech Lands from 1090, identifying two important drought rich periods (in 1863-1874 and 2004-2012). Cook et al. (2015) constructed an 'Old World Drought Atlas' (OWDA) dating from the eleventh century using instrumental records, tree-rings and documentary sources to identify mega-droughts and pluvials. Others have reconstructed long-term gridded monthly and seasonal precipitation records for Europe using proxy sources and long-term observational data sets (e.g. Casty et al., 2007). Casty et al. (2005) revealed that 1540, 1921 and 2003 were the three driest years in the last 500 years 
Carlow - 1

Dublin - 2

Kildare - 3

Kilkenny - 4

Laois - 5

Longford - 6

Louth -7

Meath -8

Offaly -9

Westmeath -10

Wexford - 11

Wicklow - 12

Clare - 13

Cork - 14

Kerry -15

Limerick - 16

Nth Tipperary - 17

Sth Tipperary - 18

Waterford - 19

Galway - 20

Leitrim -21

Mayo - 22

Roscommon - 23

Sligo - 24

Cavan - 25

Donegal - 26

Monaghan -27

Antrim - 28

Armagh - 29

Derry - 30

Down - 31

Fermanagh -32

Tyrone -33

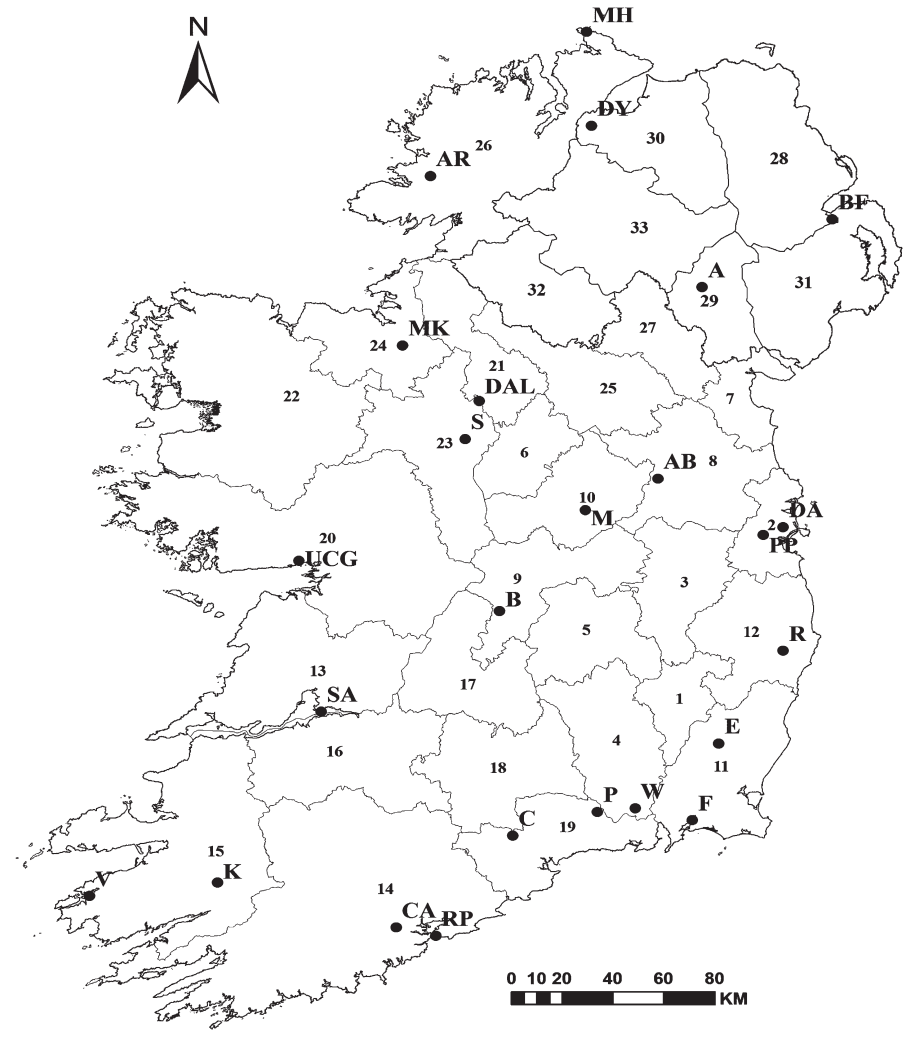

Ardara -AR

Derry - DY

Malin Head - MH

Armagh - A

Belfast - BF

Strokestown - S

Markree Castle - MK

Drumsna - DAL

Birr - B

Athboy - AB

UC Galway - UCG

Cappoquinn - $\mathrm{C}$

Mullingar - $M$

Phoenix Park - PP

Dublin Airport - DA

Shannon Airport - SA

Portlaw - P

Foulkesmills - F

Enniscorthy - E

Rathdrum - RD

Valentia - V

Cork Airport - CA

Killarney - K

Roches Point - RP

Waterford -W

Figure 1. Location of the 25 stations in the IIP network and the abbreviated station names used in later figures. Also shown are counties of Ireland to provide context for documentary references to locations.

for the European Alps. Pauling et al. (2006) find that the driest seasons in the past 500 years occurred in winter 1774, spring 1686 and autumn 1669 with extremely dry summers in 1666 and 1669. Despite their increasing availability, such long-term precipitation reconstructions have generally been under-utilized for drought assessment.

In Ireland, less detailed work has been conducted on historical droughts. O'Laoghog (1979) investigated the impacts of the severe drought of 1974-1976. Mac Cárthaigh (1996) analysed the 1995 drought from a water management perspective. Single-site analysis of drought at Armagh Observatory highlights that the lowest rainfall amounts since records began in 1836 fell between April and August 1975 (O'Laoghog, 1979). Beyond recent experience, historical droughts were briefly discussed by Dooge (1985) for the period AD 759-1408. More recently, Wilby et al. (2015a, 2015b) examined the persistence of meteorological droughts using the Island of Ireland precipitation (IIP) network 1850-2010 (Noone et al., 2015). This study demonstrated the potential for below average rainfall to persist for periods in excess of nine seasons (winter and summer half years). Examples include long dry-spells up to ten seasons in length at Belfast (1853-1858), Cappoquinn (1969-1973), Phoenix Park (1903-1908) and Strokestown (1912-1919), thus highlighting Ireland's vulnerability to long dry-spells (Wilby et al., 2015a, 2015b).
The objectives of this work are twofold: first, this research seeks to develop a detailed drought catalogue for the island of Ireland (IoI) that consolidates and builds on previous work to provide a fuller understanding of the drought climatology of Ireland. In doing so, the Standardized Precipitation Index (SPI) is applied to the recently established IIP network (Noone et al., 2015) to identify drought events for the period 1850-2015. To extend the analysis further, available precipitation reconstructions for the period 1765-1849 are employed. Second, documentary sources, particularly newspaper archives are employed extensively to (1) support the quantitative findings and (2) explore the socio-economic impacts of notable droughts. The historical drought catalogue and corresponding quantitative data presented in this study will provide a detailed historical perspective on droughts in Ireland over the last 250 years. Section 2 describes the datasets and methods employed; results are presented in Section 3 with the main findings and future work discussed in Section 4; the conclusions are set out in Section 5.

\section{Data and methods}

\subsection{Observed rainfall 1850-2015}

The IIP network (Noone et al., 2015) consists of homogenous monthly rainfall totals for 25 stations (Figure 1) and an IoI series calculated as the arithmetic mean of all 
Table 1. Seasonal bridging results in updating eight IIP network stations. Listed for each station is the neighbouring (donor) station used for updating, the seasonal correction factor $(\mathrm{CF})$ used together with the coefficient of determination $\left(R^{2}\right)$ and $\mathrm{MAE}(\mathrm{mm})$ for each seasonal regression (intercept zero).

\begin{tabular}{|c|c|c|c|c|c|c|c|c|c|c|c|c|c|}
\hline \multirow[t]{2}{*}{ IIP station } & \multirow[t]{2}{*}{ Donor station (overlap) } & \multicolumn{3}{|c|}{ Winter } & \multicolumn{3}{|c|}{ Spring } & \multicolumn{3}{|c|}{ Summer } & \multicolumn{3}{|c|}{ Autumn } \\
\hline & & $R^{2}$ & $\mathrm{CF}$ & MAE & $R^{2}$ & $\mathrm{CF}$ & MAE & $R^{2}$ & $\mathrm{CF}$ & MAE & $R^{2}$ & $\mathrm{CF}$ & MAE \\
\hline Belfast & $\begin{array}{l}\text { Hillsborough } \\
(1961-2010)\end{array}$ & 0.83 & 0.87 & 3.39 & 0.85 & 0.95 & 1.94 & 0.81 & 0.98 & 6.54 & 0.84 & 0.90 & 0.26 \\
\hline Birr & Victoria Lock & 0.63 & 1.01 & 2.10 & 0.82 & 1.05 & -1.02 & 0.63 & 0.94 & 3.38 & 0.69 & 1.00 & 0.15 \\
\hline Ardara & Glenties (1941-2010) & 0.77 & 0.89 & -3.61 & 0.86 & 0.90 & -3.02 & 0.87 & 0.87 & 9.85 & 0.89 & 0.89 & 0.49 \\
\hline Athboy & $\begin{array}{l}\text { Delvin Castle } \\
(2000-2010)\end{array}$ & 0.72 & 1.08 & 3.55 & 0.86 & 1.10 & 1.90 & 0.51 & 0.89 & 6.54 & 0.92 & 1.03 & 0.25 \\
\hline Derry & $\begin{array}{l}\text { Coleraine Cuts } \\
(1961-2010)\end{array}$ & 0.68 & 0.98 & 4.17 & 0.61 & 1.01 & -2.11 & 0.64 & 0.97 & 6.98 & 0.62 & 1.00 & 0.30 \\
\hline UC Galway & Knock (1997-2010) & 0.76 & 0.99 & 1.52 & 0.53 & 1.09 & -0.76 & 0.65 & 1.02 & 2.64 & 0.63 & 1.00 & 0.11 \\
\hline Cappoquinn & $\begin{array}{l}\text { Station House } \\
(2002-2010)\end{array}$ & 0.83 & 0.80 & -0.79 & 0.76 & 0.79 & -0.43 & 0.95 & 0.75 & 1.46 & 0.93 & 0.80 & 0.06 \\
\hline Enniscorthy & $\begin{array}{l}\text { Bunclody } \\
\text { (2002-2010) }\end{array}$ & 0.87 & 0.82 & 2.41 & 0.90 & 0.85 & -1.24 & 0.88 & 0.91 & 4.32 & 0.86 & 0.90 & 0.18 \\
\hline
\end{tabular}

stations. Noone et al. (2015) used the HOMogenisation softwarE in R (HOMER) package (Mestre et al., 2013) and station metadata to homogenize and infill/extend all records for the period 1850-2010. Here, all stations in the IIP network and the IoI series are updated to December 2015 using data provided by the Irish meteorological service (Met Éireann). Where station closures have occurred or no data were available, bridging using correlated neighbouring station records was undertaken using linear regression (intercept of zero) to derive seasonal adjustments (as in Noone et al., 2015). The updated IIP network and IoI series are employed to identify historic droughts over the period 1850-2015. Results of the IIP network update to December 2015, together with stations used for updating and the seasonal corrections applied are presented in Table 1. Of 25 IIP stations, 17 were updated by appending the 2011-2015 data to station records. For eight stations, bridging to neighbouring gauges using seasonal regressions was necessary due mainly to station closures. Seasonal adjustments range from 0.75 at Cappoquinn for summer to 1.10 at Athboy for spring. The largest mean actual error (MAE) $(9.85 \mathrm{~mm})$ in monthly totals is associated with the bridging of summer precipitation between Glenties (donor) and Ardara (IIP station). We note that, for some stations the seasonal adjustments were made using only 96 months of available data and highlight that the absence of longer-term overlaps may affect how well bridging captures inter-decadal variability at receiver sites.

\subsection{Reconstructed rainfall $1765-1849$}

Casty et al. (2007) provide gridded monthly precipitation reconstructions for the North Atlantic/European area $\left(80-30^{\circ} \mathrm{N}\right.$ and $\left.50^{\circ} \mathrm{W}-40^{\circ} \mathrm{E}\right)$ for the period December 1765-November 2000. Pauling et al. (2006) describe the methods used to reconstruct precipitation - with data from 1900 onwards being the gridded CRU TS2 reanalysis (Mitchell and Jones, 2005). To further extend the drought analysis, gridded precipitation reconstructions were extracted for the Irish land area to produce a series
Table 2. Details of monthly adjustments made to reconstructed precipitation. The coefficient of determination $\left(R^{2}\right)$ and mean absolute error (MAE) $(\mathrm{mm})$ are shown for regressions on overlapping years between reconstructed series and the IoI series (1900-2000). Also shown are the resultant adjustment factors applied to reconstructed precipitation to derive the IoIext series (1765-1849).

\begin{tabular}{lccc}
\hline Month & $\begin{array}{c}R^{2} \\
\text { coefficient }\end{array}$ & $\begin{array}{c}\text { Adjustment } \\
\text { factor }\end{array}$ & $\begin{array}{c}\text { Mean } \\
\text { absolute error }\end{array}$ \\
\hline January & 0.73 & 1.05 & 2.56 \\
February & 0.75 & 1.09 & 2.80 \\
March & 0.74 & 1.00 & 2.26 \\
April & 0.76 & 1.05 & 2.13 \\
May & 0.84 & 1.03 & 1.78 \\
June & 0.74 & 0.96 & 4.10 \\
July & 0.77 & 0.98 & 2.88 \\
August & 0.84 & 0.96 & 1.72 \\
September & 0.80 & 1.09 & 3.14 \\
October & 0.74 & 1.01 & 2.70 \\
November & 0.68 & 1.05 & 3.75 \\
December & 0.76 & 1.05 & 1.91 \\
\hline
\end{tabular}

of monthly rainfall totals. Monthly regressions (intercept of zero) were derived for data overlapping the IoI series (1850-2000) and used to adjust the reconstructed to the homogenized IoI series. This extended monthly series (December 1765-December 1849) is referred to as IoIext. In assessing drought characteristics, the IoIext series (1765-1849) was analysed separately to the IoI series and IIP network (1850-2015). Following extraction of monthly precipitation for the IoI from Casty et al. (2007), data for the reconstructed period (1765-1849) were adjusted to the IoI series. Monthly adjustment factors derived for the overlapping period of 1850-2000 are shown in Table 2. Monthly adjustments are all within $\pm 10 \%$, while July and November show largest MAEs.

\subsection{Standardized Precipitation Index}

The widely used Standardized Precipitation Index (SPI) (McKee et al., 1993; Guttman, 1999; Lloyd-Hughes and Saunders 2002; Redmond, 2002; Van Loon, 2015) is 
used to identify drought events. This index was selected as it is applicable to monthly series, does not require additional climatological variables and is recommended as a key drought indicator (WMO, 2012). The SPI is calculated by summing precipitation over specified accumulation periods (typically, 1, 3, 6, 9, 12 and 24 months) and fitting accumulation series to a parametric distribution from which probabilities are transformed to the standard normal distribution (McKee et al., 1993; Guttman, 1999; Lloyd-Hughes and Saunders, 2002). SPI values give standard deviations from typical accumulated precipitation for a given location and time of year. This allows the frequency, duration, intensity and magnitude of drought events to be quantified and compared even across climatologically different regions (McKee et al., 1993; Lloyd-Hughes and Saunders, 2002; Jenkins and Warren, 2015). SPI values between 0.99 and -0.99 are generally considered to be near normal, -1.00 to -1.49 is moderate drought, -1.50 to -1.99 is severe drought and less than -2.00 is extreme drought (WMO, 2012).

Choice of accumulation period, reference period and statistical distribution are key methodological decisions when applying SPI. Shorter accumulation periods (1-6 months) are useful for examining agricultural drought, while longer durations (6-24 months) are more indicative of hydrological drought and water scarcity (WMO, 2012). Given the objective of examining impacts across multiple sectors the SPI-12 was derived using the 'SPEI' package in R (Beguería and Sergio Vicente-Serrano, 2013) to fit a gamma distribution to accumulated precipitation. Stagge et al. (2015) examined candidate distributions for SPI of various accumulations across Europe and confirmed the utility of the two-parameter gamma distribution for accumulation periods more than 1 month (Lloyd-Hughes and Saunders, 2002; Lennard et al., 2015). We derive SPI-12 separately for reconstructed and observed series with normalization performed relative to the median precipitation of their respective full records (i.e. 1765-1849 and 1850-2015).

\subsection{Drought identification}

Following previous analyses, drought start is defined as the month in which SPI-12 falls below -1.00 , with the return to positive values indicating the month of drought termination (Mishra and Singh, 2010; Lennard et al., 2014, 2015). Variability is examined in the drought climatology of the IoI series by deriving 30-year accumulations of SPI-12 for identified droughts in all (overlapping) 30 year periods from 1881 to 2015. Additional statistics were derived for each drought event, including:

1. Duration: number of months from start to termination.

2. Accumulated deficit: sum of SPI-12 values during the event.

3. Mean deficit: accumulated deficit divided by drought duration.

4. Maximum intensity: minimum SPI-12 value achieved during the event.
Given the focus on long droughts, this study uses these statistics to identify events in the IoI and Iolext series of more than 18 months duration. Though subjective, selection of 18 months allows us to look in detail at droughts exceeding approximately the 80th percentile of all events in terms of duration. Given the impracticality of identifying uniform start and end dates for events across 25 stations, drought rich periods are examined in the IIP network. For the purposes of this study, these events are defined as those years in which at least $40 \%$ of the stations in the IIP network experience drought events of at least 18 months duration.

\subsection{Documentary sources}

Documentary evidence is used to confirm the occurrence of drought events and to examine their socio-economic impacts. Digitized and searchable historical print media are accessed through the Irish Newspaper Archive (www .irishnewsarchive.com) and the Irish Times Newspaper Archive (http://www.irishtimes.com/archive). Sixteen national and regional titles are included (Table 3) which collectively span various political positions. Of particular note are the Belfast Newsletter and the Freeman's Journal which began reporting in the early and mid-eighteenth century, respectively. A further nine titles commence in the nineteenth century with many continuing to present day. Drought start and end dates identified from the SPI analysis were used to guide the search of newspaper archives for articles containing the following phrases 'drought', 'water shortage', 'water supply' or 'crop failure'. For inclusion in this analysis, an article had to refer to drought explicitly in either the title or main text. Identified articles were saved by month and year of reporting and used to develop insight into the timing of drought development, associated impacts and responses to each event. A table (Appendix S1, Supporting information) is provided that includes a direct link to each newspaper article used in the study. Additional historical documents, including: the 1851 Census of Ireland (Wilde, 1851), Richard M. Barrington's assessment of the 1887 drought (Barrington 1888), the British Rainfall report for 1887 (Symons, 1887) and Whistlecraft's Rural Gleanings or Facts worth Knowing (Whistlecraft, 1851), are used to supplement newspaper sources.

\section{Results}

Results are presented as follows: Section 3.1 chronicles drought events identified in the IoI series 1850-2015 (calculated as the arithmetic mean of all 25 IIP stations). Section 3.2 describes drought events identified in the IIP network 1850-2105 (25 individual stations) and highlights some of their socio-economic impacts using documentary evidence. Section 3.3 outlines drought events identified in the Iolext (monthly precipitation reconstructions for Ireland 1765-1849) series and presents documentary evidence of their impact. 
Table 3. Newspaper titles accessed through the Irish Newspaper Archive (www.irishnewsarchive.com). National refers to newspapers that covered all of the Ireland and National (NI) refers to newspapers that covered Northern Ireland.

\begin{tabular}{lllll}
\hline Title & Abbreviation & Start and end dates of newspaper & Coverage & $\begin{array}{c}\text { Publication } \\
\text { frequency }\end{array}$ \\
\hline Belfast Newsletter & BN & 9 January 1738-30 August 1890 & National (NI) & Daily \\
Freeman's Journal & FJ & 3 January 1763-19 December 1924 & National & Daily \\
Kerry Evening Post & KEP & 1813-1817 & Keekly \\
Tuam Herald & TH & 13 May 1837-current & Galway & Weekly \\
Nenagh Tribune & NT & 21 July 1838-current & Tipperary & Weekly \\
Irish Examiner & IE & 30 August 1841-1999 & National & Daily \\
The Nation & N & 15 October 1842-5 June 1897 & Dublin & Weekly \\
Tralee Chronicle & TC & 18 March 1843-20 May 1881 & Kerry & Daily \\
Anglo-Celt & AC & 6 February 1846-current & Cavan & Weekly \\
Western People & WP & 4 May 1889-current & Mayo & Weekly \\
Meath Chronicle & MC & 1 May 1897-current & Meath & Weekly \\
Longford Leader & LL & 14 August 1897-current & Kerry & Weekly \\
Kerryman & K & 20 August 1904-current & National & Weekly \\
Irish Independent & II & 2 January 1905-current & Galway & Daily \\
Connacht Tribune & CT & 22 May 1909-current & National & Deekly \\
Irish Press & IP & 5 September 1931-25 May 1995 & National & Weekly \\
Irish Framers Journal & IFL & 16 March 1957-26 December 1998 & National & Weekly \\
Irish Times & IT & 29 March 1859-current & & \\
\hline
\end{tabular}

\subsection{Drought events in the IoI series (1850-2015)}

Figure 2 shows the SPI-12 index for the IoI series (1850-2015). The relative paucity of long droughts in recent years (1980s onwards) is evident, as is a tendency for more intense droughts to occur earlier in the record. In total, 45 individual drought events are identified in the IoI series for the period 1850-2015. Of these, 22 are shorter than 10 months, 19 have durations of between 10 and 20 months, and 4 last longer than 20 months. Figure 3 plots drought duration against maximum intensity and mean deficit for all identified events, while Table 4 presents the top 10 droughts in the IoI series ranked by duration, accumulated deficit, mean and maximum intensity. In the IoI series, the longest drought occurred from 1854 to 1860, persisting for 73 months with maximum intensity of SPI-12 $=-2.84$. The most intense drought occurred from 1887 to 1889 recording a minimum SPI-12 $=-3.14$ in February 1888. The most recent drought in the top 10 based on duration occurred between June 1975 and February 1977. This event ranked 6th, lasted 20 months and had the highest mean SPI-12 over the period of drought (SPI-12=-1.55). Figure 3 highlights the lack of notable droughts since the 1980s. Variability in drought climatology for the IoI series is further assessed in Figure 4. This plots accumulations of SPI-12 for identified droughts in all 30 year periods from 1881 to 2015 (i.e. 1881 represents the 30 years $1850-1881$, and so on). The relative paucity of prolonged drought events in recent years underlines the value of using long-term data to establish a more comprehensive picture of the island's drought climatology.

3.2. Drought rich periods across the IIP network (1850-2015)

Figure 5 shows the SPI-12 matrix plotted for all 25 stations in the IIP network with values colour coded based on drought severity. It is clear that many drought events identified in the IIP series have been island-wide in extent. Also evident is the tendency for severe droughts to cluster in time. The relative paucity of droughts in recent decades noted in the IoI series is also evident across individual stations. A detailed drought catalogue for each of the 25 stations in the IIP network is provided in the Appendix $\mathrm{S} 1$, where all drought events for each station are listed along with information on the duration, the mean, total accumulated and minimum SPI-12 values for each event. Here, attention is focused on understanding the development of drought and attendant socio-economic impacts during drought rich periods.

Using the definition of a drought rich period as years in which at least $40 \%$ of the stations in the IIP network experience events of at least 18 months duration, the following periods are noted: $1854-1860,1884-1896$, 1904-1912, 1921-1923, 1932-1935, 1952-1954 and 1969-1977. Figure 6 shows the progression and spatial distribution of these events in more detail. Of note is the diversity of drought signatures in terms of their severity and spatio-temporal development. For instance, the events of 1884-1896 and 1969-1977 are marked by intermittent periods of extreme and moderate drought conditions, while the events in 1854-1860, 1932-1935 and 1952-1954 are characterized by prolonged, severe drought conditions. The 'long drought' of 1854-1860 previously identified in the IIP network (Wilby et al., 2015a, 2015b) and UK (Marsh et al., 2007) series is evident. However, in the south and southeast this event appears more intense but shorter in duration. The drought period of 1921-1923 is the least spatially extensive of those considered and falls just short of meeting the criteria set out for drought identification. However, we include it in our analysis as it has been recorded as an event of note in other work covering Ireland (Cook et al. 2015) and the UK (e.g. Lennard et al. 


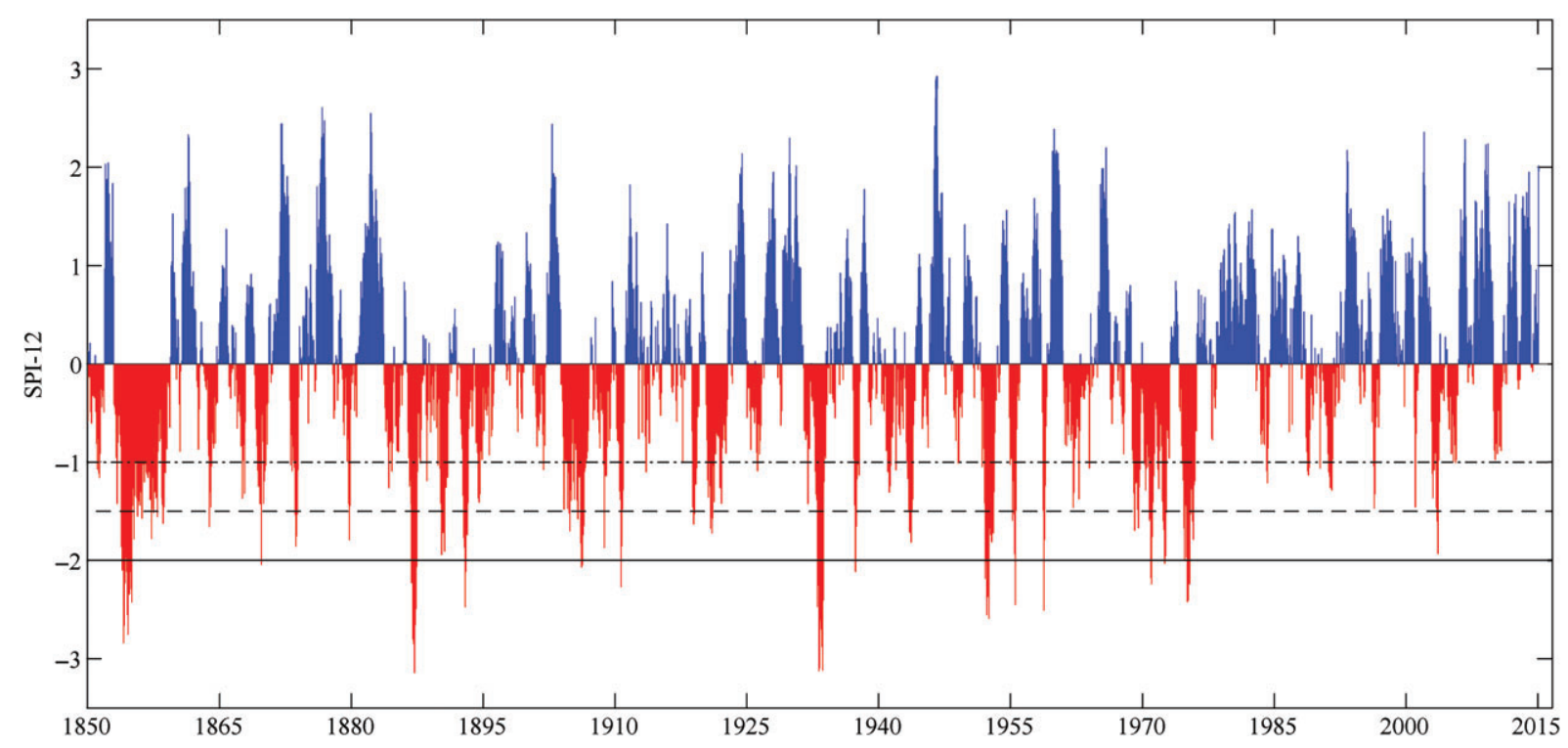

Figure 2. SPI-12 series for the IoI series 1850-2015. Dotted horizontal line is the threshold for drought start (-1.0), the dashed horizontal line is the threshold for severe drought $(-1.5)$ and solid horizontal line is the threshold for extreme drought $(-2.0)$.
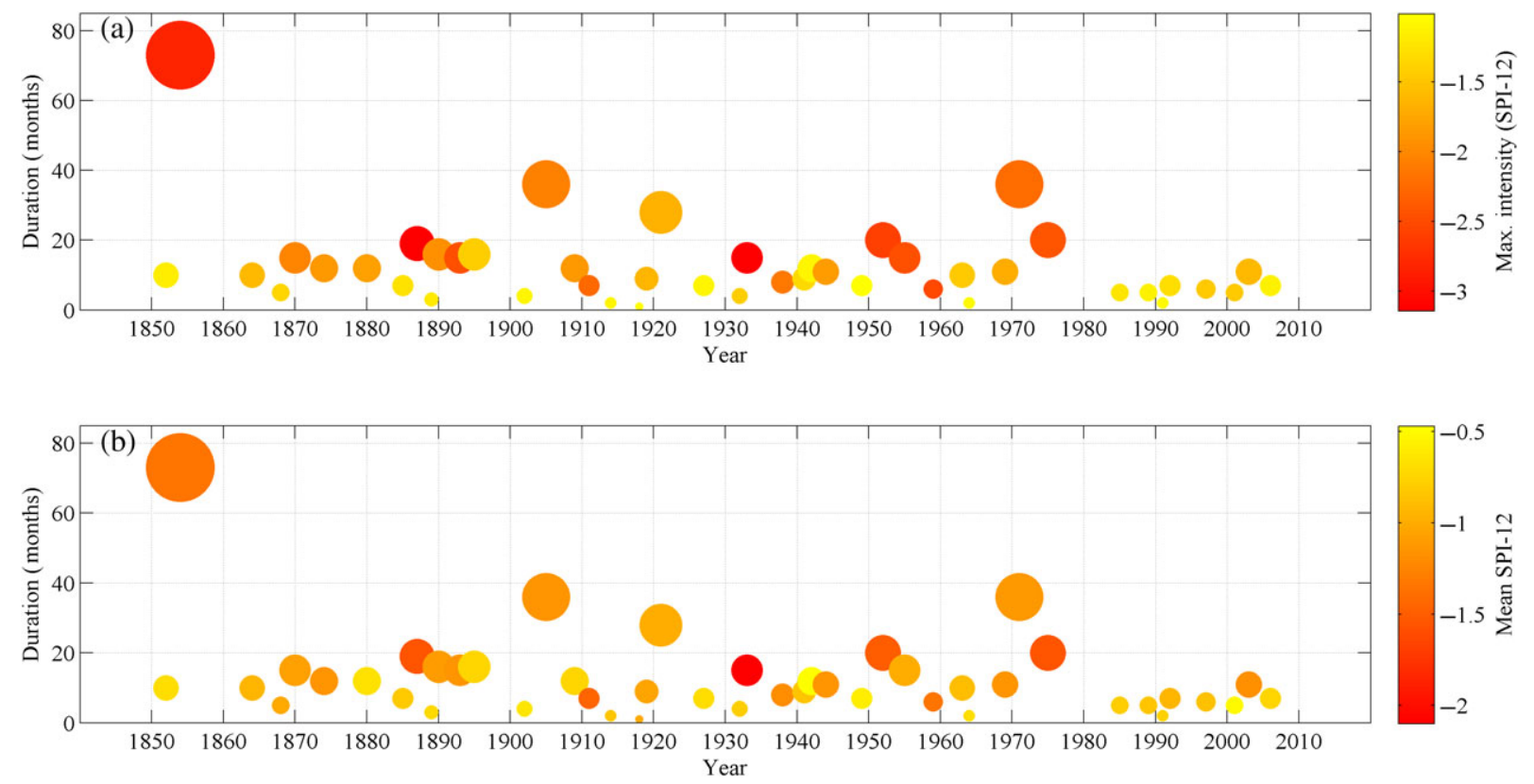

Figure 3. Drought duration plotted against (a) maximum intensity and (b) mean SPI-12 for each of the 45 droughts identified in the IoI series 1850-2015. Circle size denotes duration (months) while the colour ramp indicates intensity and mean SPI-12, respectively.

2015), respectively. For this period, extreme drought conditions are noted as persisting for a relatively long-period at a small number of stations. In the following sections, each of the drought rich periods identified above are further analysed, furthermore their development and impacts are traced with reference to documentary evidence using the sources outlined in Section 2.5. Note that when tracing the evolution of each drought, the date of publication of newspaper articles is also provided.

\subsection{1. $1854-1860$}

This drought began in December 1853 in the northeast, spreading to western and northern regions by January
1854. It extended south to Shannon by April 1854. Drought reached other parts of the south and southeast around September 1854. In all regions drought persisted until April/May 1860, lasting more than 70 months at 16 stations in the IIP network. The drought was most intense in the south and southeast with minimum SPI-12 values for Valentia (-3.99), Cork $(-3.83)$, Killarney $(-3.14)$ and Waterford $(-2.87)$ recorded between January and April 1855.

There are references to the start of drought in several newspapers (AC, 27.04.1854, page 2; FJ, 27.05.1854, page 4). The Freeman's Journal notes the increasing cost of agricultural produce at Dublin Market with a lack of fodder 
Table 4. Top ten drought events identified in the IoI series (1850-2015) separately ranked by mean SPI deficits, accumulated SPI deficits, drought duration in months and maximum SPI intensity (min. SPI-12 value) recorded during each event.

\begin{tabular}{lcccc}
\hline Rank & Mean SPI-12 & Accumulated deficit & Drought duration(month) & Maximum intensity \\
\hline 1st & -2.10 & -97.54 & 73 & -3.14 \\
& $(1933-1934)$ & $(1854-1860)$ & $(1854-1860)$ & $(1887-1889)$ \\
2nd & -1.55 & -41.48 & 36 & -3.12 \\
& $(1975-1977)$ & $(1905-1908)$ & $(1905-1908)$ & $(1933-1934)$ \\
3rd & -1.54 & -40.47 & 36 & -2.84 \\
& $(1887-1889)$ & $(1971-1974)$ & $(1971-1974)$ & $(1854-1860)$ \\
4th & -1.49 & -31.55 & 28 & -2.59 \\
& $(1952-1954)$ & $(1933-1934)$ & $(1921-1923)$ & $(1952-1954)$ \\
5th & -1.45 & -30.98 & 20 & -2.51 \\
& $(1911-1912)$ & $(1975-1977)$ & $(1952-1954)$ & $(1959-1960)$ \\
6th & -1.34 & -29.74 & 20 & -2.47 \\
& $(1854-1860)$ & $(1952-1954)$ & $(1975-1977)$ & $(1893-1894)$ \\
7 th & -1.34 & -29.29 & 19 & -2.45 \\
& $(1959-1960)$ & $(1887-1889)$ & $(1887-1889)$ & $(1955-1957)$ \\
8th & -1.20 & -27.86 & 16 & -2.42 \\
& $(1938-1938)$ & $(1921-1923)$ & $(1890-1892)$ & $(1975-1977)$ \\
9th & -1.16 & -17.64 & 16 & -2.27 \\
& $(2003-2004)$ & $(1890-1892)$ & $(1895-1896)$ & $(1911-1912)$ \\
10th & -1.15 & -17.08 & 15 & -2.24 \\
& $(1905-1908)$ & $(1893-1894)$ & $(1870-1881)$ & $(1972-1974)$ \\
\hline
\end{tabular}

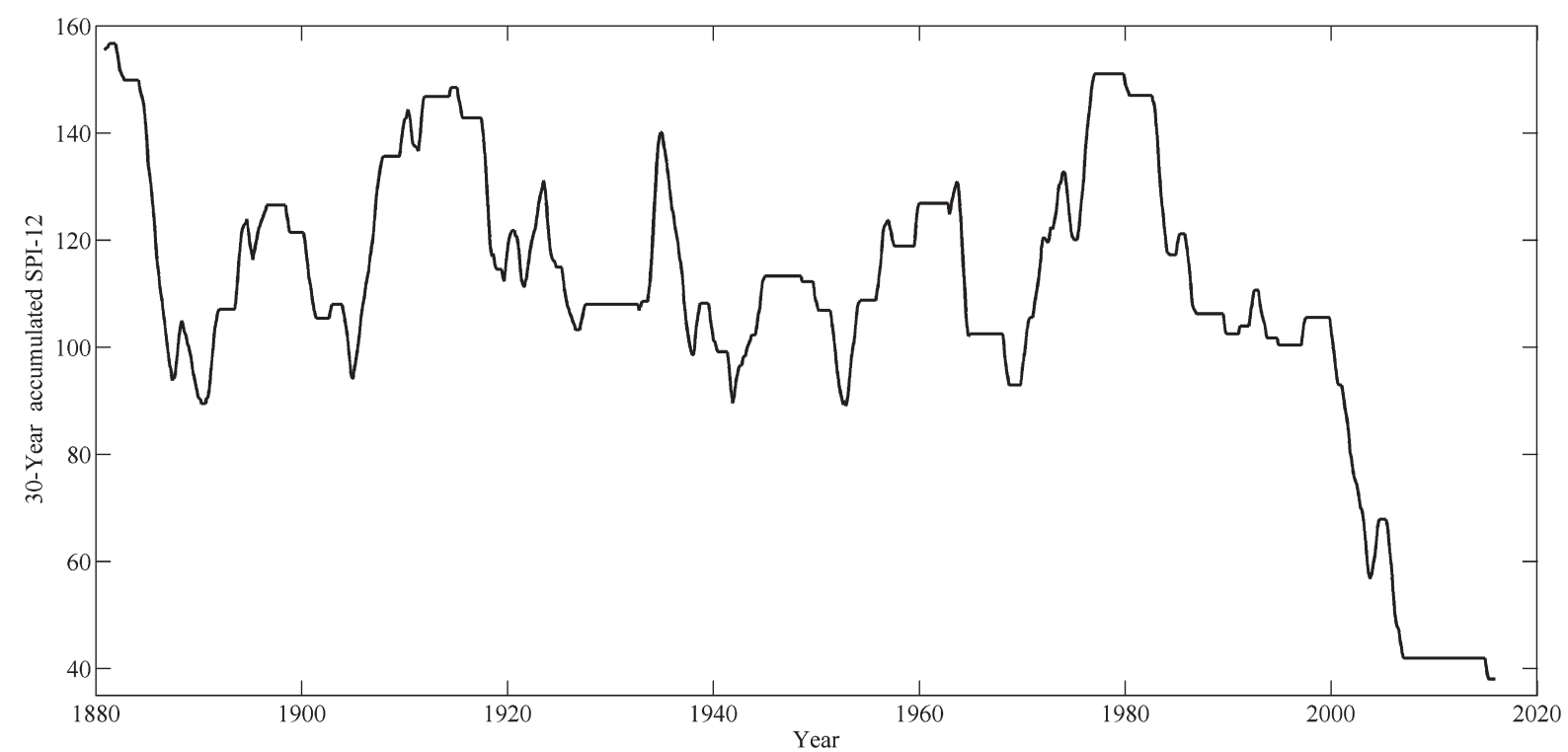

Figure 4. Thirty-year accumulated SPI-12 values for identified drought events in the IoI series. Note that the end year of each 30-year accumulation period has been used to define the $x$-coordinate plotting position, and that the accumulated SPI values have been multiplied by -1 so that lower values indicate a deficit of dry conditions.

and unusually late potato and wheat crops (FJ, 04.05.1855, page 4). The Irish Examiner reports that the soil was very absorbent with rainfall being soaked up by the parched earth (IE, 07.06.1854, page 4). Due to the scarcity of pasture many cows remained dry of milk and unsold at the Dublin market, with similar conditions and falling prices experienced at other monthly fairs across the island (IE, 07.06.1854, page 4).

Some respite came with rainfall across specific regions in summer 1854. While some crops recovered in time for harvesting, rainfall was not sufficient to relieve drought conditions ( $\mathrm{N}, 08.07 .1854$, page 14). Later in the drought there are also accounts of sporadic wet weather. However, there are also references to rain events that made the land unfit for yielding crops due to the soil damage caused by the preceding drought (IE, 30.05.1859, page 2; TC, 21.06.1859, page 2; BN, 31.05.1859, page 4; BN, 01.06.1859, page 2). The summer of 1859 saw severe water shortages for Dublin City. Restrictions by order of Dublin City Hall were in place on both domestic and manufacturing water usage as well as a complete ban on watering the streets (FJ, 12.07.1859, page 1). By early 1860, agriculture was in a 'distressing condition' with crop failures, rotted wheat and livestock suffering from a lack of grass (FJ, 10.07.1860, page 2). By May and early June 1860 rainfall returned and, although wells were dry and 


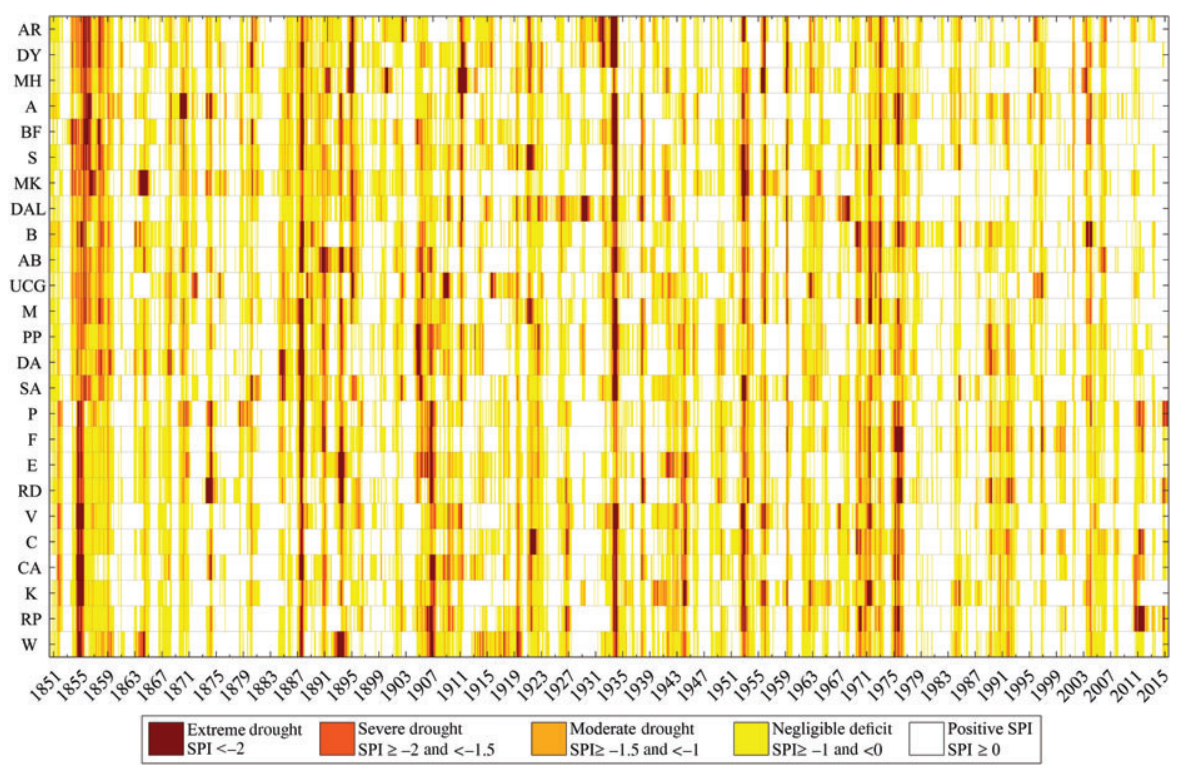

Figure 5. SPI-12 values for all 25 stations in the IIP network. Negative SPI-12 values are colour coded according to severity thresholds to highlight periods of moderate to extreme drought conditions.

groundwater supplies depleted, heavy continuous rainfall replenished stocks to a satisfactory state $(\mathrm{FJ}, 29.05 .1860$, page 4; FJ, 02.06.1860, page 3; FJ, 10.07.1860, page 2; FJ, 15.07.1806, page 2).

\subsection{2. $1884-1896$}

The period 1884-1896 saw severe multi-year droughts punctuated by periods of positive SPI values. Evidence indicates that the most intense and widespread drought during the period 1850-2015 occurred in 1887. This event began between May and June 1887 along the east coast and spread island-wide. Event duration was more than 30 months at most stations, with Strokestown registering the longest event duration (60 months). Maximum intensity was experienced at Dublin (-3.54), while the largest accumulated deficit was experienced at Ardara (-105.02).

Barrington (1888) described widespread crop failures across Ireland in 1887 with barley, oats and potatoes stocks severely depleted. However, it appears conditions suited the wheat crop in the northeast and southeast. The 1887 drought caused widespread crop failures, reduced vegetable growth and livestock losses in Clare, Tipperary, Wexford, Antrim, Galway, Kerry and Dublin (N, 15.10.1887, page 11; IT, 26.06.1887, page 3; IT, 02.07.1887, page 5; IT, 06.07.1887, page 5; IT, 08.07.1887, page 6; IT, 03.09.1887, page 7). Drought also impacted the linen trade in the north with factories closed due to lack of water-power (IE, 25.08.1887, page 4). In August 1887, low water pressure in Dublin caused problems when responding to fire in the city centre (IT, 09.08.1887, page 4). Reductions in tram receipts were attributed to excess dust caused by the drought (IT, 31.08.1887, page 3). Sewerage systems were reported blocked due to lack of water, leading to public health concerns (IT, 30.06.1887, page 6; IT, 21.07.1887, page 5).
Extreme drought returned in spring 1893 across the south, east and southeast. Waterford, Rathdrum and Enniscorthy stations show drought conditions lasting until July/August 1896 with peak SPI-12 intensities below -3.00 . The west, northwest and some midland stations experienced less severe deficits with drought terminating earlier. The 1893 drought depleted water levels in the Vartry reservoir, Dublin's major water source (FJ, 14.03.1894, page 7), with water leakages from a degraded distribution network deemed to have exacerbated the public water supply situation. The event saw demands for a repair and monitoring programme and debate over potential new water sources for the city (IT, 23.11.1893, page 6; FJ, 14.03.1894, page 7).

\subsection{3. $1904-1912$}

The drought began in October 1904 in the east and northeast and was evident in all stations by June 1905. Drought duration varied from 10 months at Armagh to 64 months at Dublin. The peak severity $(-3.03)$ at Cork in the south was recorded in March 1907. Regions worst affected were in the south, east and some areas of the southwest. This period of drought was episodic, punctuated by intermittent rainfall events. Levels in the inland navigation canal and Royal canal fell to an extent that reduced their navigability (II, 08.09.1911, page 4). The reservoir located in the midlands at Longford dried up completely (II, 08.09.1911, page 4). With the exception of Ardara and Malin Head, where drought persisted until December 1912, by June 1912 most areas were back to near normal conditions.

\subsection{4. $1921-1923$}

The severe 2-year drought of 1921-1923 began in February 1921 across the midlands and west regions. However, by summer 1921 all areas were affected. Strokestown 


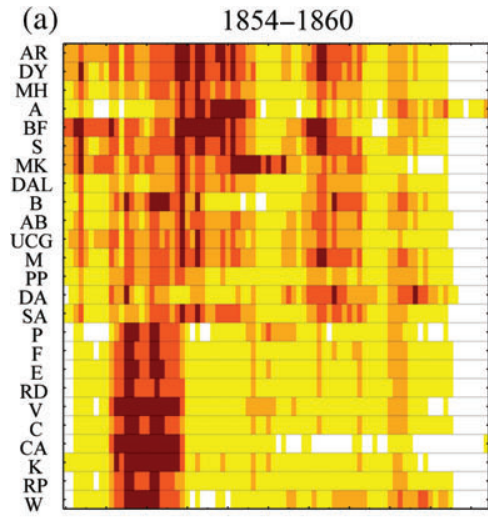

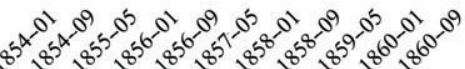

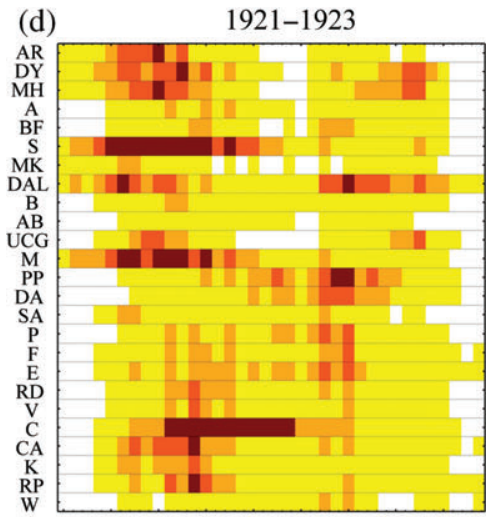

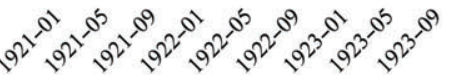

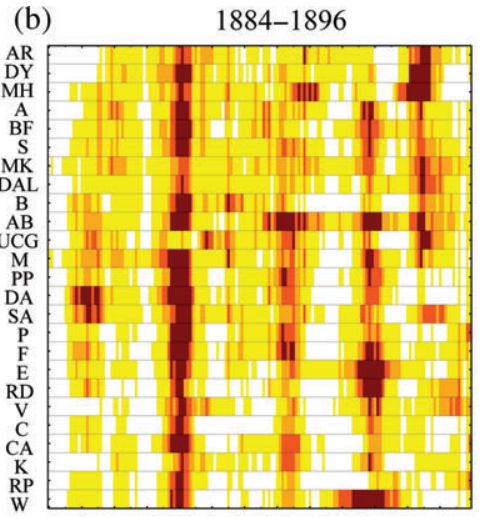

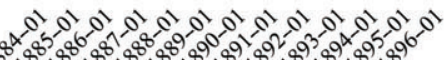

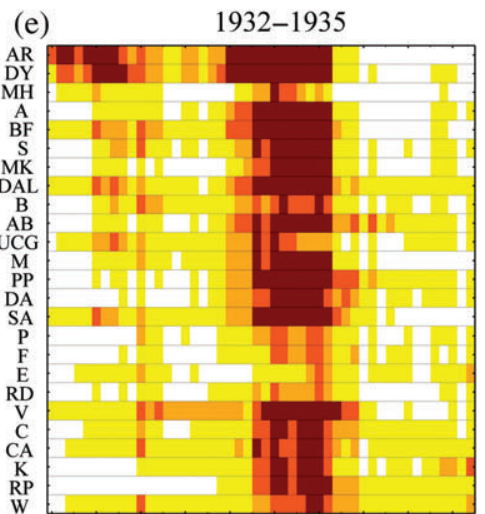

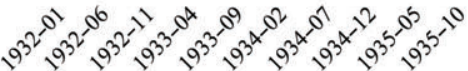

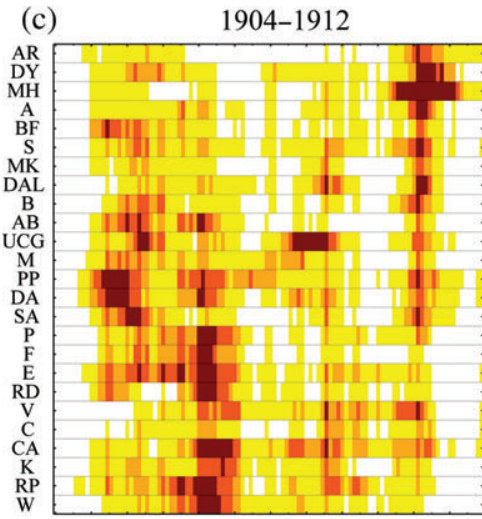

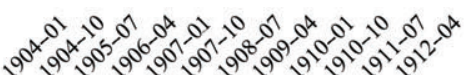

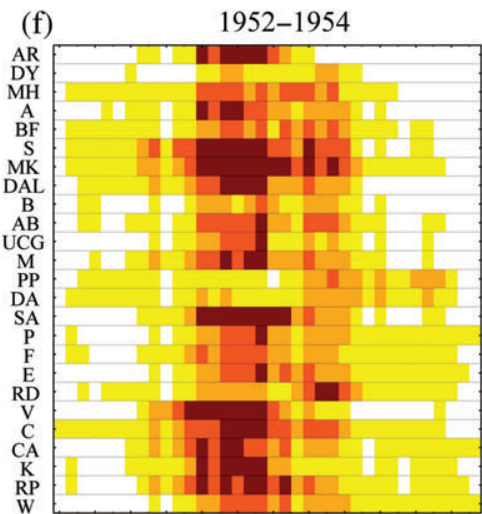

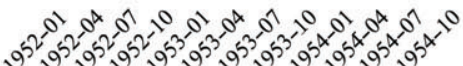
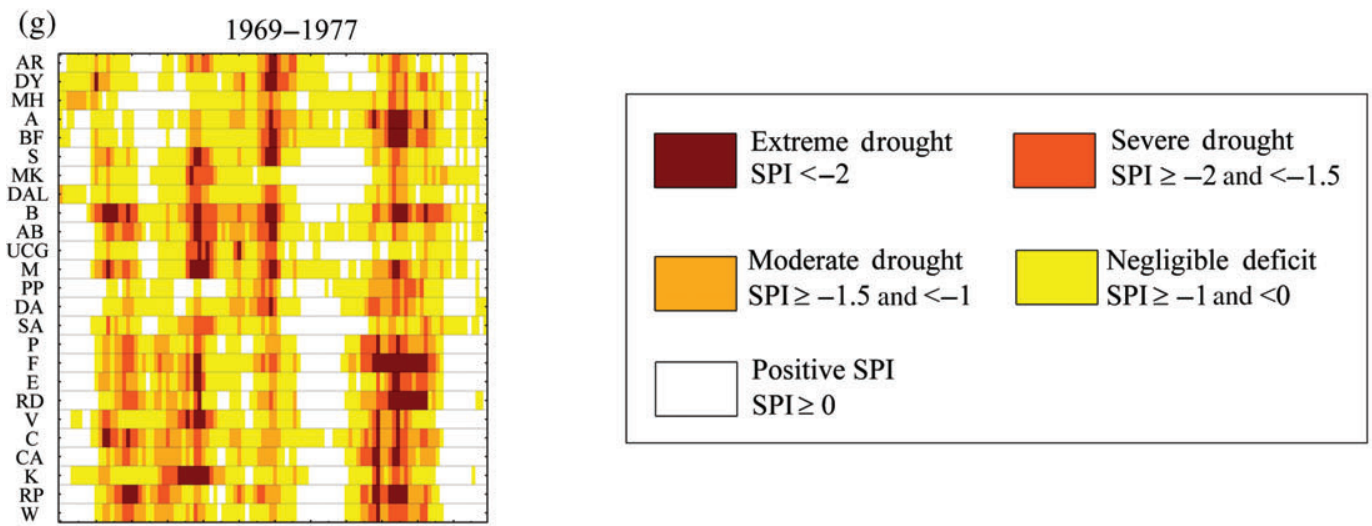

$a_{0.90}$

Figure 6. Drought signatures showing SPI-12 values for all stations in the IIP network for the seven drought periods identified with island-wide impact. Negative SPI-12 values are colour coded according to severity thresholds to highlight periods of moderate to extreme drought conditions.

recorded the greatest peak intensity $(-3.56)$ in October 1921. In the east, the drought peaked several months later in January 1923 but was less severe $(-2.25)$ at Phoenix Park. Drought duration varied between 11 and 32 months, causing widespread water restrictions (II, 20.06.1921, page 4). There were also concerns that the Vartry reservoir would dry up completely, with comparisons made to the 'Great Drought' of 1893 (II, 20.06.1921, page 4).

\subsection{5. $1932-1935$}

The first signs of drought appeared at Ardara and Valentia in October 1931, Derry in February 1932, spreading to the other stations in the south/southwest by summer/autumn and the rest of the island by autumn 1933. The greatest intensity was experienced at Derry (-4.38) and Ardara $(-3.79)$; with the drought persisting the longest at Ardara 


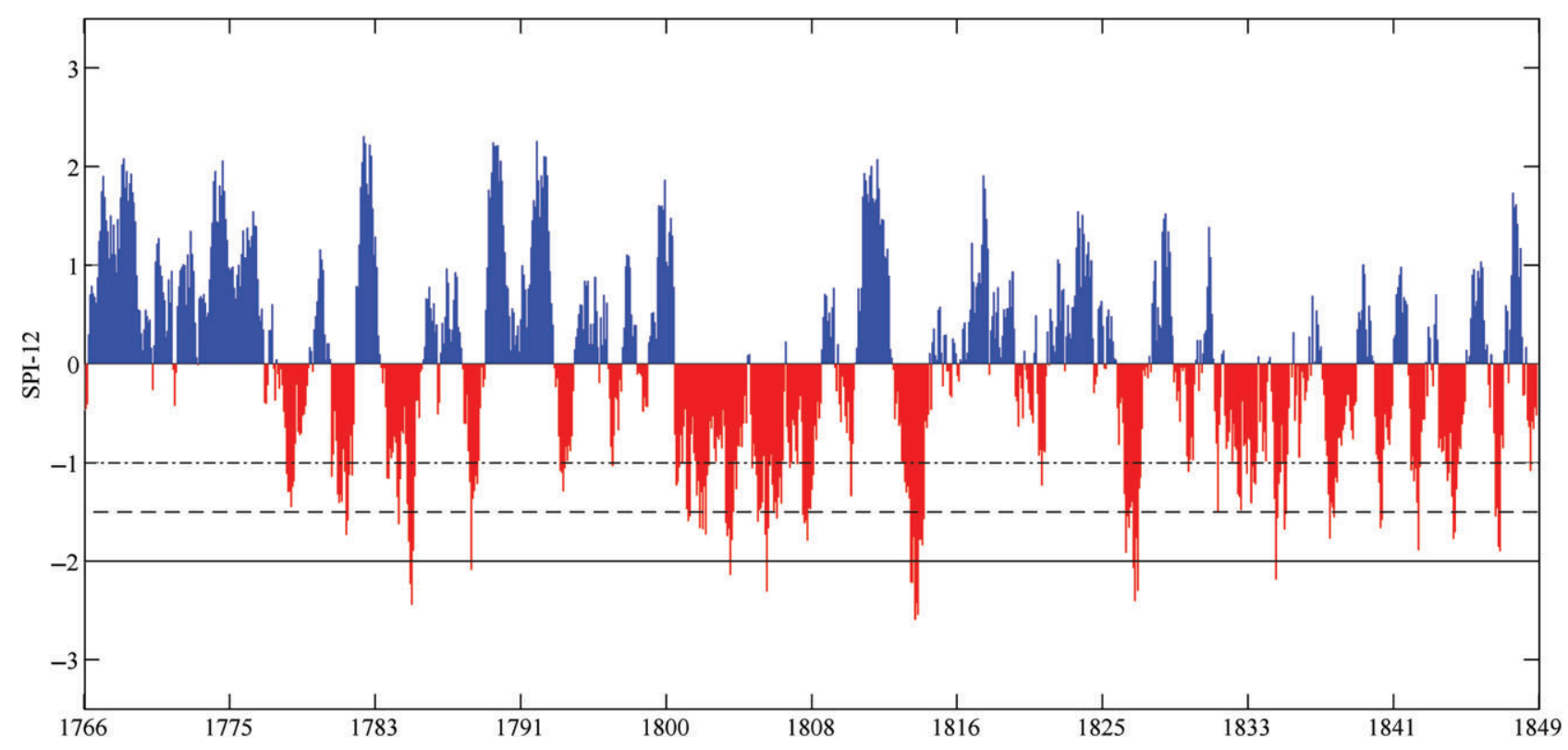

Figure 7. SPI-12 series for the island of Ireland extended (IoIext) series 1765-1849. Dotted horizontal line is the threshold for drought start ( -1.0 ), the dashed horizontal line is the threshold for severe drought $(-1.5)$ and solid horizontal line is the threshold for extreme drought $(-2.0)$.

(69 months) [but note potential issues found in the metadata around 1931 for Ardara in Noone et al. (2015)]. At 12 stations the drought lasted longer than 25 months, terminating at most stations by November 1934. Farmers in Wexford experienced water shortages with ponds, springs, wells and streams drying up (IE, 25.07.1934, page 5). Milk and butter yields were well below normal and beet and turnips crops failed (IE, 25.07.1934, page 5). Low reservoir levels in Enniskillen in the north impacted flax growers and in Clonmel (in the south) residents were asked to stop watering gardens unnecessarily (IP, 08.08.1935, page 1).

\subsection{6. $1952-1954$}

A further severe 2-year drought began in November/December 1952 and persisted in most areas until August/September 1954. Stations in the west, midlands, northwest and south were severely affected, with Shannon recording the greatest intensity ( -3.41 ; June 1953). Drought duration ranged from 12 months at Derry to 24 months at Portlaw. Newspaper reports state that milk yields were diminished, rivers and lakes were well below normal levels and tillage growth was reduced due to hard ground (II, 27.03.1953, page 2; NG, 14.02.1953, page 5). Hydroelectric output was also well below average (LL, 10.10.1953, page 9). During 1952/3 there were also reports of a marked reduction in the quantity of salmon, oysters and eels due to an insufficient flow of water in the weirs located at Castleconnell and Thomond, County Limerick (Electricity Supply Board, 1953; LL, 10.10.1953, page 9).

\subsection{7. $1969-1977$}

This period is marked by a clustering of drought events. The first began across most stations in October 1969 and terminated in August 1970 across northwest, northeast and west regions. The midlands, south and southeast were more severely affected with Birr recording a peak drought intensity of -2.86 in January 1970. Drought returned to most stations by autumn 1971 with greatest intensity at Killarney (-2.99) in September 1971. Drought duration of 53 months was recorded at Belfast. The event terminated in December 1973 at most stations but persistent drought conditions returned to all stations by August 1975. The southeast, south and northeast were severely affected. Armagh recorded the lowest SPI-12 value (-3.05) in January 1976 , with SPI-12 values persistently below -2.00 for several months. Most stations located in the midlands, south and southeast recorded persistent SPI-12 values of this magnitude for more than 4 months during the summer of 1976. All stations returned to near normal conditions by August 1977. Drought impacts included reduced levels in reservoirs supplying water to Dublin City, provoking stringent water restrictions (O'Laoghog, 1979). Water supplies were stressed in 1976 due to increased demand during the previous summer and insufficient replenishment during the intervening dry winter (O'Laoghog, 1979). The severe lack of water for livestock and the poor condition of crop and grazing lands affected agriculture (WP, 19.07.1975, page 22).

\subsection{Reconstructed drought events 1765-1849}

For the period of reconstructed rainfall (1765-1849), Figure 7 plots SPI-12 for the IoIext series. Of note is the lack of drought in the early record $(\sim 1766$ to 1775). In total 23 droughts are identified throughout the reconstructed period, seven of which are shorter events lasting less than 10 months. Figure 8 plots the duration of all droughts in the IoIext against their maximum intensity and mean SPI-12. Evident is the 

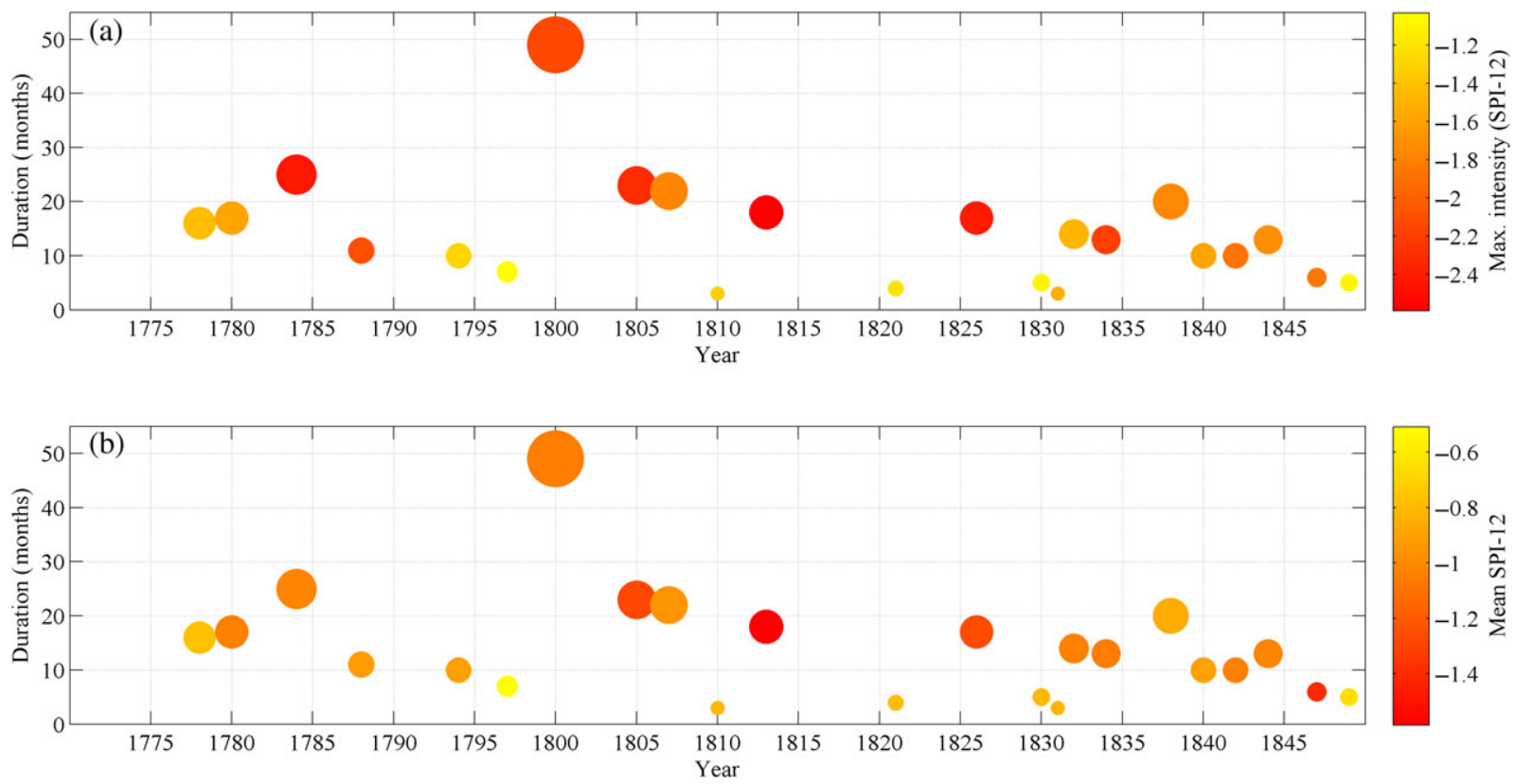

Figure 8. Drought duration plotted against (a) maximum intensity and (b) mean SPI-12 for each of the 23 droughts identified in the IoIext series 1765-1849. Circle size denotes duration (months) while the colour ramp indicates intensity and mean SPI-12, respectively.

long, intense event around 1800-1804 (49 months), followed closely by two shorter but also intense events in 1805-1806 (23 months) and 1807-1809 (22 months). These three droughts are only briefly punctuated by near normal conditions and are treated as continuous drought periods below.

Shorter, but particularly intense droughts are noted in 1813-1815 (18 months), 1826-27 (17 months) and 1838-1839 (20 months). The latter occurs within a cluster of events from approximately 1830 to 1849 , which tend to be relatively brief but intense events. Notable is that the Great Irish Famine of 1845-1852 occurred during this period of intermittent drought. The following sections provide an overview of key impacts for long drought events in this Iolext series. Although the 1826-27 event lasted for 17 months, it is included below because it coincided with the famine of 1826 . Table 5 gives statistical details on each drought and an overview of the accompanying documentary evidence.

\subsection{1. $1784-1786$}

The drought of 1784-1786 lasted 25 months with an accumulated deficit of -25.61 reaching maximum intensity $(-2.43)$ in July 1785 . Newspaper articles refer to extreme drought throughout Europe, England and southern parts of Ireland in 1785 (BN, 20.06.1788, page 3; BN, 22.07.1785, page 2; FJ, 03.09.1785, page 3). Symons (1887) also notes that 1785 was a year that experienced 'remarkable heat and drought', while Garnier et al. (2015) mention reduced productivity in textile and flour industries due to water shortage. Ó Gráda (2015) makes reference to the drought of 1784-1786 and subsequent famine, noting that disease was rife and a temporary embargo was placed on distilling and grain exports.

\subsection{2. $1800-1809$}

The sequence of droughts between 1800 and 1809 was the most remarkable in the entire 250-year record analysed. The first drought began in September 1800 and lasted 49 months until October 1804 - with an accumulated deficit of -51.33 and maximum intensity ( -2.13 ; October 1803$)$. Following a 3-months respite, the second drought phase commenced in January 1805 and lasted 23 months until December 1806, with an accumulated deficit of -29.24 and maximum intensity $(-2.30)$ in November 1805. After another 3 months of near normal SPI-12 values, the third drought phase began in March 1807, lasted 22 months until January 1809 , recording an accumulated deficit of -21.02 and maximum intensity of $(-1.78)$ in March 1808.

There is evidence that, at least early stages of the event, drought effects were not island-wide with counties Leitrim and Roscommon producing potatoes and other crops for supply to severely impacted areas in the south and west (FJ, 03.01.1801, page 2). In 1802, Irish officials put in place financial support to import maize from the United States to alleviate the emergency (Ó Gráda, 2015). There are also a number of references to this period in the 1851 Census, which notes that summer of 1800 was unusually hot and dry, and in the period June-September 1803 Ireland was 'nearly burned by drought', with springs and rivulets drying up (Census, 1851). There is also evidence of this being a severe drought period across the UK and Europe with reports of poor crop growth and livestock dying (IT, 09.01.1801, page 2; IT, 06.02.1802, page 5; FJ, 11.01.1803, page 2; FJ, 15.06.1805, page 2).

\subsection{3. $1813-1815$}

Within the IoIext series this event lasts 18 months (September 1813-February 1815) with an accumulated 
Table 5. Details of the seven drought events identified for analysis from the IoIext series (1765-1849). Also presented is the duration of each event (month) together with associated documentary evidence.

\begin{tabular}{lcl}
\hline Year & Duration (month) & Summary of socio-economic impacts \\
\hline $1784-1786$ & 25 & $\begin{array}{l}\text { Rivers and lakes in England completely dried up, } \\
\text { livestock died. }\end{array}$ \\
& $\begin{array}{l}\text { Ireland 1785 'remarkable heat and drought'. } \\
\text { Linen mills could not work due to lack of river flow. } \\
\end{array}$ & A temporary embargo was placed on Irish distilling
\end{tabular}

$1800-1804$
A temporary embargo

Famine occurred with diseases such as 'fever, dysentery, scarlatina, ophthalmia and influenza' all rife.

The woollen industry declined in 1802 due to lack of water to work the mills.

1800 and 1801 summer temperatures 'very hot' rarely experienced before.

June 1803 Ireland was 'nearly burned by drought'.

Springs and rivers completely dried up.

Potato crop failures, the main food source at this time causing severe hardship.

1799-1801 famine with potato crops extremely scarce.

The drought which had prevailed in England gave farmers such serious alarm.

Defective crops and produce falling short of usual yields due to drought.

After several weeks of intolerable heat and great drought the earth has been refreshed with rain showers. June, July and August 1815 very hot with exceptionally mild winter.

In England many ponds and rivers dried up.

Grass became very scarce.

Drought preceded the Irish famine of 1816-1818 when $40000-60000$ Irish people lost their lives. Reports that not a shower of rain had fallen since the 27th May 1826.

Temperatures reached $115^{\circ}$ Fahrenheit on Sunday 25th June.

Ireland 1826 'not a breath of air stirs' and no clouds could be seen in the sky.

Ireland 1826 continued to experience very hot temperatures and excessive drought.

The summer of 1826 had not occurred in the living memory of the oldest man.

Irish farmers named this as 'the year of short oats'. Crops in a poor state, wool production reduced and hop growth depleted.

Dry scorching wind, Ireland was experiencing severe weather and the sun has been very strong.

Lack of upland crop growth, with flax seed growing but not a very healthy crop

Famine in Ireland during 1839 with high prices of potatoes but little excess mortality
FJ, 09.09.1800, page 3

FJ, 15.07.1806,

page 2

Census (1851)

Whistlecraft

(1851)

Kelly (1992)

Garnier et al.

(2015)

FJ, 15.06.1805

page 2

BF, 11.08.1807,

page 2

FJ, 28.07.1807,

page 2

Census (1851)

Symons (1887)

Kelly, (1992)

Ó Gráda, (2015)

FJ, 28.06.1826,

page 4

BN, 22.08.1826,

page 2

$\mathrm{BN}, 06.07 .1827$,

page 2

Census (1851)

Symons (1887)

McSweeny (1831)

FJ, 06.06.1839,

page 4

Ó Gráda (2015) deficit of -28.53 and maximum intensity $(-2.59)$ in May 1814. The 1851 Census reports that June, July and August 1815 were very hot and winter 1815 very mild, although there is no reference to rainfall. The Freeman's Journal reports that in October 1814 the drought had increased corn and wheat prices forcing brewers to use alternative ingredients, sometimes with poisonous consequences (FJ, 15.10.1814, page 3). This intense drought immediately precedes the Irish famine of 1816-1818 when 40000-60000 Irish people lost their lives (Kelly, 1992; Ó Gráda, 2015). This event is also noted in England where Symons (1887) mentions that many ponds and rivers dried up and grass became very scarce. 


\subsection{4. $1826-1827$}

Commencing in May 1826 and terminating in September 1827 (17 months) this was a severe drought with SPI-12 values less than -1.50 for seven consecutive months coinciding with the famine of 1826 , causing severe hardship to the population (McSweeny, 1831; Ó Gráda, 2015). The drought reached a maximum intensity $(-2.40)$ in December 1826. Linen Hall, Belfast was reported as having very low rainfall throughout the summer of 1826 (Barrington, 1888). Farmers were forced to harvest crops early. However, due to the severe drought, early potato crops failed, pastures suffered severely and cattle prices were very low (IT, 11.07.1826, page 3; BN, 22.08.1826, page 2).

\subsection{5. $1838-1839$}

This drought rich period consisted of a cluster of events that occurred between 1830 and 1849. The drought began in January 1838 and terminated 20 months later in September 1839 , reaching an accumulated deficit of -17.18 and maximum intensity $(-1.76)$ in February 1838. There are reports that both flour and oatmeal arrived slowly to markets due to drought in 1838 (LE, 20.10.1838, page 4). In the southeast farmers told of soil that was so dry it was difficult to cultivate and that both the tillage and growth of the potato crop was delayed in 1839 (FJ, 21.05.1839, page 2; FJ, 04.06.1839, page 4). In June 1839, the Freeman's Journal notes that in many parts plants were parched, vegetation had made little growth and the drought was so severe that the ground was difficult to work (FJ, 06.06.1839, page 4). In 1839, Ireland experienced a famine with potatoes at a very high price causing hardship but relatively small increases in mortality (Ó Gráda, 2015).

\section{Discussion}

The assessment of drought occurrence and impacts presented here yields new insights into the experience of drought in Ireland. The IoI (1850-2015) and IoIext (1765-1849) series reveal 68 individual drought events over the last 250 years. Fourteen long duration droughts (>18 months) are identified, with seven in each of the IoI (Table 4) and Iolext (Table 5) series. Table 4 presents the top ten ranked droughts based on mean intensity, accumulated SPI deficits, duration and maximum intensity. Depending on which metric is prioritized a different set of events and ranking is returned highlighting the difficulty of using a single metric in drought analysis. For example, the drought event of 1854-1860 is ranked first for duration and accumulated SPI deficits but drought events in 1887-1889 and 1933-1934 rank first for maximum SPI intensity and mean SPI, respectively.

Impacts from severe drought periods include reduced or failed crop yields, increased crop and dairy prices, human and livestock health issues, water restrictions, low reservoir levels, water supply failures and hydro-power reductions. During the period 1765-1849 many long duration events occur during or immediately prior to famine events in 1782-1784, 1800-1801, 1816-1818, 1839 and 1845-1849 (Great Irish Famine) (Ó Gráda, 2015). Across this analysis, two long duration events are particularly noteworthy: the drought of 1800-1809 (in fact a series of three droughts with brief 3 month interludes) and the continuous event of 1854-1860 (73 months).

A key insight gained is the relative paucity of droughts in recent decades, particularly since the 1980s. Although occasional intense drought events have occurred in this period (e.g. 1995, 2006, 2013) these have been relatively short-lived (Figure 4). Thus, in comprehensively characterizing drought climatology the study demonstrates the added-value of long records. The assessment of drought accumulations over continuous 30-year periods for the IoI series (1850-2015) highlights the unusualness of the recent record and how unrepresentative the period since 1980 is of the long-term drought climatology of the island. The period of subdued SPI-12 accumulations around the 1990s (Figure 4) is consistent in timing with the regime shift in Atlantic Ocean influence on European climate identified by Sutton and Dong (2012). It is also notable that three of the top ten wettest summers in the IoI series since 1850 have occurred since $2000(2007,2008,2009)$ (Noone et al., 2015). Matthews et al. (2015) note an increase in storminess in summer in recent decades and Wilby et al. (2015a, 2015b) highlight that the probability of a dry half-year followed by another dry half-year is currently lowest since 1850. Important future work is to explore the potential drivers of change in the recent experience of droughts to ascertain the likelihood of a return to longer duration events of earlier centuries. We note that there has been limited exploration to date regarding the impacts of anthropogenic climate change on droughts for Ireland. Roudier et al. (2016) highlight that hydrological drought magnitude and duration may increase in Ireland in a $2{ }^{\circ} \mathrm{C}$ warmer world. However, large uncertainties surround projections of rainfall for the IoI. While increases in winter rainfall are expected, the direction of change in summer rainfall is highly uncertain (Matthews et al., 2016; Murphy et al., 2013).

Assessment of drought across the 25 stations in the IIP network (1850-2015) shows general coherence with findings from the IoI series. Seven drought rich periods are identified across the island in 1854-1860, 1884-1896, 1904-1912, 1921-1923, 1932-1935, 1952-1954 and 1969-1977, revealing substantial variations in terms of drought development, severity and spatial extent across the network as a whole (Figure 6). For instance, 1884-1896 is characterized by spatially uniform clusters of extreme drought events, while $1854-1860$ is characterized by protracted drought conditions with the event being markedly shorter and more severe in the southeast. Drought in the period $1921-1923$ is the least spatially coherent and less severe. This is in contrast to $1932-1935$ where 21 stations experienced maximum SPI-12 values greater than -2.00 (Figure 6). Results for the period 1969-1977 show that drought across the west and northwest was generally less severe than the south and southeast. This contrasts with earlier droughts (e.g. 1854-1860, 1884-1896, 
1932-1935) where all regions were severely affected. Such diversity questions the practice of using single events for tasks such as drought planning. Uncovering the climatological drivers of drought rich periods (e.g. Moreira et al., 2015) would facilitate a deeper understanding of past events. Such knowledge is critical for establishing how climate variability and change might influence future drought occurrence.

The drought catalogue draws extensively on documentary sources, particularly newspaper records, digitized and made searchable by the Irish Newspaper Archive. Such sources contain some of the longest running publications in the world and offer unique insights into the socio-economic impacts of drought. There is scope to utilize the documentary evidence to qualitatively extend the drought analysis back prior to 1765 . This research also shows that such archives can be used to trace evolving drought situations and their impacts. These independent sources also increase confidence in the quantitative findings of drought indicators, particularly for droughts falling in the period prior to available digitized records (typically 1940 in Ireland) or the reconstructed Iolext series. This study advocates wider use of newspapers in understanding the impacts and climatology of historic droughts, and we note the many references to UK drought within the early Irish print media. Murphy et al. (2016) further elaborate on insights offered by the documentary archive compiled here.

Given that evaporative losses can exacerbate summer drought it would be preferable to use a drought indicator that incorporates this variable (e.g. Standardized Precipitation-Evaporative Index; Vicente-Serrano et al., 2010). However, long-term, quality assured series of evaporation or temperature are not yet available for the IoI. Work is ongoing to derive a temperature series by transcribing and homogenizing archived records. This will facilitate assessment of shorter droughts (e.g. SPI-3) and reconstruction of river flows to examine hydrological drought (as in Jones et al., 2006). Pre-1850 droughts are based on reconstructed data and thus findings must remain tentative. However, corroboration of the drought events by documentary evidence from various sources increases confidence. Moreover, throughout the 250 years analysed there are many similarities with drought periods identified in neighbouring regions of the UK such as 1800-1809, 1826 and 1833-3 (e.g. Cole and Marsh 2006; Marsh et al., 2007; Todd et al., 2013). Cook et al. (2015) identify persistent drier than average conditions over north-central Europe during the period 1779-1827. The same study identified a major long drought across UK and Wales during 1798-1808, while Scotland and Ireland experienced 50-90\% below average rainfall in 1893. Cook et al. (2015) also noted that during 1921 London (UK) experienced the driest year since 1774, all these drought periods are comparable with those identified in this study.

As with any drought assessment subjective decisions were necessary that may have influenced results. Firstly the SPI metric was chosen given data availability and its wide use (McKee et al., 1993; Guttman, 1999; Lloyd-Hughes and Saunders 2002; Redmond, 2002; Van Loon, 2015). Following Lennard et al. (2015) drought start and end dates were identified when SPI-12 fell below -1.00 and recovered to positive values. Use of different start and end criteria would obviously change the duration, accumulated deficits and mean intensity of identified droughts. Similarly, this study chose SPI-12 (12 month accumulation) to identify long drought periods that impact on multiple sectors (e.g. agriculture and water). The use of SPI at lower accumulations (e.g. SPI-6) would also reduce the length of identified drought events. Nonetheless, we are confident that the same drought rich periods would emerge with a different study design. The criterion for selection of events with island-wide impact was set at $40 \%$ of stations experiencing drought lasting at least 18 months. This allowed us to focus on events exceeding the 80th percentile in terms of duration and was informally chosen to identify a manageable number of events for further study. This is in line with Wilby et al. (2015a, 2015b) who regarded a drought event as widespread when more than two thirds of stations in the IIP network of 25 stations report a dry season or event. Again, we remain confident that our analysis has identified the most noteworthy droughts in terms of their spatial impact.

Finally, these findings have significant implications for future infrastructure and water resource planning, while facilitating resilience assessment of critical services under severe drought conditions. When advising Irish local authorities developing climate change adaptation strategies; Gray (2016) recommends adopting a 30-year window as appropriate to identify weather extremes and climatic trends in assessing resilience to climate variability. This work clearly shows that where vulnerability to drought is an issue, such guidance would result in considerable maladaptation with potentially serious consequences. The combination of droughts of various duration, evolution and intensity identified here provide a diverse set of conditions under which to stress-test current and planned infrastructure, particularly in the water sector (e.g. Watts et al., 2012; Spraggs et al., 2015). To this end, this work provides detailed information on all droughts (duration, mean intensity, accumulated deficits and maximum intensity) identified for each of the 25 IIP network stations (1850-2015) as Appendix S1. Practitioners can identify the most suitable event or combination of historical events for the purpose at hand. The IIP network dataset is freely available for use and download at www .met.ie/download/Long-Term-IIP-network.zip or by email with the author.

\section{Conclusions}

This research has developed a 250-year drought catalogue for Ireland. Employing the Standardized Precipitation Index (SPI) to identify droughts across 25 stations in the IIP network and an IoI series shows that the region is surprisingly drought prone. During the period 1850-2015, 
seven major drought rich episodes are identified that impact simultaneously at least $40 \%$ of the study sites in $1854-1860,1884-1896,1904-1912,1921-1924$, 1932-1935, 1952-1954 and 1969-1977. The detailed analysis of SPI metrics highlights the substantial diversity of events in terms of drought development, severity and spatial extent across the island.

Extension of the analysis to 1765 revealed a further seven drought rich periods, of particular note being the period 1800-1809. Extensive integration of documentary sources from newspaper archives increases confidence in the droughts identified across the 250 years of record. The work shows the value-added by combining qualitative and quantitative evidence of historical droughts to arrive at a more coherent understanding of their development and impacts.

Perhaps the most important finding of this study is that recent decades are not representative of the long-term drought climatology of Ireland. Hence, there is a danger that infrastructure and water resource plans benchmarked against the 1995 drought may underestimate the potential supply deficits that could occur with a return to conditions experienced in the eighteenth and nineteenth centuries. Further research is needed to improve understanding of the ocean-atmosphere drivers associated with periods of more persistent drought in Ireland. Past severe droughts can also be used to stress-test the resilience of planned water resource developments, at least to the climate variability experienced over the last 250 years.

\section{Acknowledgements}

We are indebted to historical figures who produced some incredible resources which we employ here, particularly Richard M. Barrington for his detailed assessment of the 1887 drought (Barrington, 1888) and William Wilde (father of Oscar) in compiling past weather and climate extremes in the 1851 Census of Ireland. SN was funded by the Irish Research Council. CM, CB and CD acknowledge funding provided by Environmental Protection Agency grant no. 2014-CCRP-MS.16.

\section{Supporting information}

The following supporting information is available as part of the online article:

Appendix S1. Detailed tables (Tables S1-S27) of drought events and table listing details of the archived newspaper articles used in this study together with direct links to the newspaper articles.

\section{References}

Barker PA, Wilby RL, Borrows J. 2004. A 200-year precipitation index for the central English Lake District. Hydrol. Sci. J. 49(5): 769-785, doi: 10.1623/hysj.49.5.769.55131.

Barrington RM. 1888. The drought of 1887, and some of its effects on Irish agriculture. J. Stat. Soc. Inquiry Soc. Ireland IX(Pt LXVII): $223-247$.
Beguería S, Sergio Vicente-Serrano SM. 2013. SPEI: Calculation of the Standardised Precipitation-Evapotranspiration Index. $R$ package version 1.6. http://CRAN.R-project.org/package\&equals;SPEI (accessed 7 August 2016)

Brázdil R, Dobrovolný P, Trnka M, Kotyza O, Řezníčková L, Valášek H, Zahradníček P, Štěpánek P. 2013. Droughts in the Czech Lands, 1090-2012 AD. Clim. Past 9(4): 1985-2002, doi: 10.5194/cp-9-1985-2013.

Briffa KR, van der Schrier G, Jones PD. 2009. Wet and dry summers in Europe since 1750: evidence of increasing drought. Int. J. Climatol. 29: 1894-1905, doi: 10.1002/joc. 1836.

Casty C, Wanner H, Luterbacher J, Esper J, Böhm R. 2005. Temperature and precipitation variability in the European Alps since 1500. Int. J. Climatol. 25: 1855-1880, doi: 10.1002/joc.1216.

Casty C, Raible CC, Stocker TF, Wanner H, Luterbacher J. 2007. A European pattern climatology 1766-2000. Clim. Dyn. 29: 791-805, doi: 10.1007/s00382-007-0257-6.

Census. 1851. Census Report of Ireland, 1851, Part V, Vol. 1. Dublin, Ireland: Alexander Thom and Sons. http://www.histpop.org/ last accessed 07/06/2016 (accessed 4 July 2016).

Cole GA, Marsh TJ. 2006. An historical analysis of drought in England and Wales Climate Variability and Change - hydrological impacts. In Proceedings of the Fifth FRIEND World Conference held at Havana, Cuba, November 2006. IAHS Publ. 308.

Cook ER, Seager R, Kushnir Y, Briffa KR, Büntgen U, Frank D, Krusic PJ, Tegel W, van der Schrier G, Andreu-Hayles L, Baillie M, Baittinger C, Bleicher N, Bonde N, Brown D, Carrer M, Cooper R, Čufar K, Dittmar C, Esper J, Griggs C, Gunnarson B, Günther B, Gutierrez E, Haneca K, Helama S, Herzig F, Heussner K-U, Hofmann J, Janda P, Kontic R, Köse N, Kync T, Levanič T, Linderholm H, Manning S, Melvin TM, Miles D, Neuwirth B, Nicolussi K, Nola P, Panayotov M, Popa I, Rothe A, Seftigen K, Seim A, Svarva H, Svoboda M, Thun T, Timonen M, Touchan R, Trotsiuk V, Trouet V, Walder F, Ważny T, Wilson R, Zang C. 2015. Old World megadroughts and pluvials during the common Era. Sci. Adv. 1(10): e1500561-e1500561, doi: 10.1126/sciadv. 1500561.

Dooge JCI. 1985. Droughts in Irish history. In Irish Rivers, de Buitléar É (ed). Country House Press: Dublin, 26-28.

Electricity Supply Board. 1953. 26th Annual Report of the Electricity Supply Board Ireland for the year ended March 1953. https:// ruralelectric.files.wordpress.com/2016/02/esb-annual-reports_19521953.pdf (accessed 10 June 2016).

Fink AH, Brücher T, Krüger A, Leckebusch GC, Pinto JG, Ulbrich U. 2004. The 2003 European summer heatwaves and drought synoptic diagnosis and impacts. Weather 59(8): 209-216, doi: 10.1256/wea.73.04.

Garnier E, Assimacopoulos D, van Lanen HAJ. 2015. Historic droughts beyond the modern instrumental records: an analysis of cases in United Kingdom, France, Rhine and Syros. DROUGHT-R\&SPI Technical Report No. 35 Seventh Framework programme CNRS-Université de Caen Basse Normandie, France; NTUA-National Technical University of Athens, Greece; WU, Wageningen University, The Netherlands.

Gosling R, Zaidman M, Wann M, Rodgers PJ. 2012. How low can you go? Using drought indices to protect environmental flows in Scottish Rivers. In BHS Eleventh National Symposium, Hydrology for a Changing World. British Hydrological Society: Dundee, 6.

Gray S. 2016. Local Authority Adaptation Strategy Development Guidelines (2012-CCRP-FS-14). Prepared by University College Cork for the Environmental Protection Agency, Wexford, Ireland. https://www.epa.ie/pubs/reports/research/climate/EPA_Research_ Report164.pdf (accessed 30 July 2016).

Guttman NB. 1999. Accepting the standardized precipitation index: a calculation algorithm. J. Am. Water Resour. Assoc. 35(2): 311-322, doi: 10.1111/j.1752-1688.1999.tb03592.x.

Hannaford J, Lloyd-Hughes B, Keef C, Parry S, Prudhomme C. 2011. Examining the large-scale spatial coherence of European drought using regional indicators of precipitation and streamflow deficit. Hydrol. Process. 25(7): 1146-1162, doi: 10.1002/hyp.7725.

Jenkins K, Warren R. 2015. Quantifying the impact of climate change on drought regimes using the standardised precipitation index. Theor. Appl. Climatol. 120(1-2): 41-54, doi: 10.1007/s00704-014-1143-x.

Jones PD, Lister DH, Wilby RL, Kostopoulou E. 2006. Extended river flow reconstructions for England and Wales, 1865-2002. Int. J. Climatol. 26: 219-231.

Kelly J. 1992. Scarcity and poor relief in eighteenth-century Ireland: the subsistence crisis of 1782-4. Irish Hist. Stud. 28(109): $38-62$. 
Kingston DG, Stagge JH, Tallaksen LM, Hannah DM. 2015. European-scale drought: understanding connections between atmospheric circulation and meteorological drought indices. J. Clim. 28: 505-516, doi: 10.1175/JCLI-D-14-00001.1.

Lennard AT, Macdonald N, Hooke J. 2014. Analysis of drought characteristics for improved understanding of a water resource system. In Evolving Water Resources Systems: Understanding, Predicting and Managing Water - Society Interactions. Castellarin A, Ceola S, Toth E, Montanari A (eds). Proceedings of ICWRS2014. IAHS, Bologna, Italy, June 2014 (IAHS Publ. 364), 404-409.

Lennard AT, Macdonald N, Clark S, Hooke JM. 2015. The application of a drought reconstruction in water resource management. Hydrol. Res., doi: 10.2166/nh.2015.090.

Lloyd-Hughes B, Saunders MA. 2002. A drought climatology for Europe. Int. J. Climatol. 22: 1571-1592, doi: 10.1002/joc.846.

Mac Cárthaigh M. 1996. An Assessment of the 1995 Drought Including a Comparison with Other Drought Years. Environmental Protection Agency: Dublin, $70 \mathrm{pp}$.

Marsh TJ. 2004. The UK drought of 2003: a hydrological review. Weather 59: 224-230, doi: 10.1256/wea.79.04.

Marsh T, Cole G, Wilby R. 2007. Major droughts in England and Wales, 1800-2006. Weather 62: 87-93, doi: 10.1002/wea.67.

Matthews T, Mullan D, Wilby RL, Broderick C, Murphy C. 2016. Past and future climate change in the context of memorable seasonal extremes. Clim. Risk Manag. 11: 37-35, doi: 10.1016/ j.crm.2016.01.004.

McKee TB, Doesken NJ, Kleist J. 1993. The relationship of drought frequency and duration of time scales. In Eighth Conference on Applied Climatology. Am. Meteorol. Soc. January 17-23, 1993, Anaheim CA, 179-186.

McSweeny J. 1831. An essay on the climate of Ireland. Trans. R. Irish Acad. 17: 179-233.

Mestre O, Domonkos P, Picard F, Auer I, Robin S, Lebarbier E, Böhm R, Aguilar E, Guikarro J, Vertachnik G, Klan-car M, Dubuisson B, Stepanek P. 2013. HOMER: a homogenization software - methods and applications. Idojaras 117(1): 47-67.

Mishra AK, Singh VP. 2010. A review of drought concepts. J. Hydrol. 391(1-2): 202-216.

Mitchell TD, Jones PD. 2005. An improved method of constructing a database of monthly climate observations and associated high-resolution grids. Int. J. Climatol. 25: 693-712, doi: 10.1002/ joc. 1181.

Moreira EE, Martins DS, Pereira LS. 2015. Assessing drought cycles in SPI time series using a Fourier analysis. Nat. Hazards Earth Syst. Sci. 15(3): 571-585, doi: 10.5194/nhess-15-571-2015.

Murphy C, Harrigan S, Hall J, Wilby RL. 2013. Climate-driven trends in mean and high flows from a network of reference stations in Ireland. Hydrol. Sci. J. 58(4): 755-772, doi: 10.1080/02626667.2013.782407.

Murphy C, Noone S, Duffy C, Broderick C, Matthews T, Wilby R. 2016. Irish droughts in newspaper archives: Rediscovering forgotten hazards? Weather. (in press).

Noone S, Murphy C, Coll J, Matthews T, Mullan D, Wilby RL, Walsh S. 2015. Homogenization and analysis of an expanded long-term monthly rainfall network for the Island of Ireland (1850-2010). Int. J. Climatol. 36: 2837-2853, doi: 10.1002/joc.4522.
Ó Gráda C. 2015. Famine in Ireland, 1300-1900, UCD Centre For Economic Research Working Paper Series 2015, UCD School Of Economics, University College Dublin, Belfield, Dublin 4.

O'Laoghog SS. 1979.The Dry Period October 1974 to August 1976 [report], Met Éireann, Internal Memorandum, 88/79, 1979, 1979-01.

Pauling A, Luterbacher J, Casty C, Wanner H. 2006. Five hundred years of gridded high-resolution precipitation reconstructions over Europe and the connection to large-scale circulation. Clim. Dyn. 26(2006): 387-405.

Redmond KT. 2002. The depiction of drought. Bull. Am. Meteorol. Soc. 83: $1143-1147$.

Roudier P, Andersson JC, Donnelly C, Feyen L, Greuell W, Ludwig F. 2016. Projections of future floods and hydrological droughts in Europe under a $+2{ }^{\circ} \mathrm{C}$ global warming. Clim. Change 135(2): 341-355.

Spinoni J, Naumann G, Vogt JV, Barbosa P. 2015. The biggest drought events in Europe from 1950 to 2012. J. Hydrol. Reg. Stud. 3: 509-524, doi: 10.1016/j.ejrh.2015.01.001.

Spraggs G, Peaver L, Jones P, Ede P. 2015. Re-construction of historic drought in the Anglian Region (UK) over the period 1798-2010 and the implications for water resources and drought management. $J$. Hydrol. 526: 231 -252, doi: 10.1016/j.jhydrol.2015.01.015.

Stagge JH, Tallaksen LM, Gudmundsson L, Van Loon AF, Stahl K. 2015. Candidate distributions for climatological drought indices (SPI and SPEI). Int. J. Climatol. 35(13): 4027-4040.

Sutton RT, Dong B. 2012. Atlantic Ocean influence on a shift in European climate in the 1990s. Nat. Geosci. 5: 788-792, doi: 10.1038/ngeo1595.

Symons GJ. 1887. British Rainfall. Edward Stanford: London.

Todd B, Macdonald N, Chiverrell RC, Caminade C, Hooke JM. 2013. Severity, duration and frequency of drought in SE England from 1697 to 2011. Clim. Change 121(4): 673-687, doi: 10.1007/ s10584-013-0970-6.

Van Loon AF. 2015. Hydrological drought explained. WIREs Water 2: 359-392, doi: 10.1002/wat2.1085.

Vicente-Serrano SM, Beguería S, López-Moreno JI. 2010. A multi-scalar drought index sensitive to global warming: the Standardized Precipitation Evapotranspiration Index - SPEI. J. Clim. 23(7): 1696-1718, doi: 10.1175/2009JCLI2909.1.

Watts G, von Christierson B, Hannaford J, Lonsdale K. 2012. Testing the resilience of water supply systems to long droughts. J. Hydrol. 414-415: 255-267, doi: 10.1016/j.jhydrol.2011.10.038.

Whistlecraft O. 1851. Rural Gleanings or Facts Worth Knowing. Hamilton, Adams \& Co.: London.

Wilby RL, Noone S, Murphy C, Matthews T, Harrigan S, Broderick C. 2015a. An evaluation of persistent meteorological drought using a homogeneous Island of Ireland precipitation network. Int. J. Climatol. 36: 2854-2865, doi: 10.1002/joc.4523.

Wilby RL, Prudhomme C, Parry S, Muchan KGL. 2015b. Persistence of hydrometeorological droughts in the United Kingdom: a regional analysis of multi-season rainfall and river flow anomalies. J. Extr. Events. 2: 1550006, doi: 10.1142/S2345737615500062.

World Meteorological Organization. 2012. Standardized Precipitation Index User Guide (Svoboda M, Hayes M, Wood, D.). WMO-No. 1090: Geneva. 